\title{
Guerreros y teólogos. Guerra santa y martirio fascista en la literatura de la cruzada del 36
}

\author{
Javier Rodrigo* \\ Universitat Autònoma de Barcelona
}

RESUMEN: Este artículo contribuye, desde el análisis de fuentes narrativas primarias, al estudio de los mecanismos de identificación con la causa sublevada en la retaguardia franquista en guerra civil. Desde una conceptualización amplia de la noción de Cruzada, observa los porqués de su aceptación generalizada. Y desde ella, señala algunas de las claves para comprender su éxito, en tanto que lenguaje para comprender, en un contexto de guerra total, al «nosotros»y al «ellos».

\section{Palabras clave: Guerra Civil; Cruzada; catolicismo; fascismo; enemigo.}

\section{Warriors and Theologians. Holy War and Fascist Martyrdom in the Crusade Lite- rature about 1936}

ABSTRACT: This paper contributes, from the analysis of primary narrative sources, to the study of the mechanisms of identification with the francoist cause in the Spanish Civil war. From a broad conceptualization of the notion of Crusade, it looks at the "whys» of their widespread acceptance. Then, it proposes some of the interpretative keys to understand its success as a language to define, in a context of total war, us and «them».

\section{KeY WORDS: Spanish Civil War; Crusade, Catholicism, Fascism, Enemy.}

* Investigador Ramón y Cajal adscrito al proyecto «Las alternativas a la quiebra liberal en Europa: socialismo, democracia, fascismo y populismo (1914-1991)» (HAR2011-25749). 


\section{INTRODUCCIÓN}

«Guerreros y teólogos» denominaría en 1942 a los excombatientes falangistas, desde la primera página del primer número de El Español, el catedrático de filosofía y y dirigente de la Falange asturiana Juan Francisco Yela Utri1la. Las fronteras entre lo bélico y lo teológico no eran nítidas a la hora de identificar el carácter último de la cultura política fascista en España. Al menos, no lo eran para el Pemartín que aseguraba que España era fascista con un avance de cuatro siglos sobre Italia o Alemania, pues solo en España podría tener un sentido absoluto la máxima de que el fascismo era una «concepción religiosa» ${ }^{1}$. Guerreros y teólogos eran los falangistas, los combatientes y excombatientes, los que habían liberado a la verdadera España. «Nuestro catolicismo fue combativo, de lucha, y nuestras guerras fueron esencialmente católicas, de religión», escribiría Yela. Falange era «cristiana», se compadecía «de las turbas», sentía «hambre y sed de justicia por los desvalidos, por las masas obreras» ${ }^{2}$. El catolicismo era su nexo de unión. Y la Cruzada, su guerra santa.

El propio general Franco lo expondría de manera más clara en 1961, veinticinco años después del golpe de Estado. Para el dictador resultaba «un atentado contra la razón y la realidad» cualquier interpretación que pretendiese «encuadrar nuestra guerra dentro de los límites clásicos y angostos de las simples guerras civiles». Estaba «en juego el ser o no ser de España» y su futuro cristiano: «de ahí que la profundidad, dimensiones y significación de nuestra guerra de Liberación rebasara desde la primera hora el área territorial española y que por sus motivaciones más radicales, por su contenido religioso y signo espiritual», fuera «autorizadamente definida como Cruzada, la guerra justa por excelencia» $\aleph^{3}$. Destinada a cohesionar la retaguardia y a legitimar la violencia contra el enemigo bajo el manto de su recreación en positivo, (como una limpieza necesaria de la patria y de la comunidad nacional de los elementos enfermos) $)^{4}$, y por más que fuese sintética e integradora, ni la noción de la Cruzada sería unívoca, ni dejaría de suscitar tensiones internas dentro de los sublevados por la consagración del relato. Lo cual era reflejo evidente de la heterogeneidad de sus orígenes intelectuales tanto cuanto de los tiempos, no siempre inmediatos, en la asunción de un relato común. A analizar algunos de los elementos centrales del discurso de los sublevados en 1936, para comprender cómo el fascismo y los fascistas hicieron suya la Cruzada y la guerra santa, quiere dedicarse este artículo. Para ello, se defenderá que el de la Cruzada fue un relato integrador de las diferentes sensibilidades y proyectos polí-

\footnotetext{
${ }^{1}$ Cit. en RODRÍGUEZ, 2008: 348. Por todos, GALLEGO, 2014.

${ }^{2}$ Catolicismo y Falange, en El Español, n. 1, 31-10-1942, pp. 1 y 4.

${ }^{3}$ El Nuevo Estado, 1961: 15-16

${ }^{4}$ RODRIGO, 2009. JULIÁ, 2006. NÚÑEZ SEIXAS, 2006. SEVILLANO, 2007.
} 
ticos de la retaguardia sublevada: en cierta medida, un coagulante identitario. Que fue un relato tremendamente exitoso, no solamente porque echase sus raíces en la religión más extendida de España, sino también porque colmaba las expectativas narrativas de la heterogénea, unión de los sublevados de 1936. Y que no fue un relato necesariamente ligado al eclesiantismo, y sí al catolicismo definitorio del fascismo español si no antes, sí al menos durante y después de la Guerra Civil. Es decir, tal como han señalado autores como Francisco Morente o Ferrán Gallego: cuando el fascismo tuvo posiciones de poder y su partido se convirtió en la base política de un movimiento de masas.

No eran todos fascistas, ni todos eclesiales, pero compartían espacios simbólicos y narrativos. En la medida en que se catolizó el fascismo, durante la guerra también se fascistizó el catolicismo. Sus relatos convergieron en territorios compartidos y porosos, espacios de definición y redefinición conceptual. Y uno de los más poderosos fue precisamente el de la Cruzada, como podrá comprobarse desde una fuente tan específica y significativa como la literario-propagandística. No hace falta acudir necesariamente a Arrarás, en buena medida más receptor que creador de discurso, para identificar una narrativa compleja pero también homogénea que, a caballo entre guerra y posguerra, dotaría de contenido al relato de la Cruzada ${ }^{5}$. Siquiera sumariamente y sin poder evidentemente hacer referencia a todas las obras implicadas en ese proceso de construcción narrativa, aquí se van a analizar a partir de algunas de sus huellas literarias algunos elementos identitarios comunes y convergentes, que sirvieron de amalgama en la retaguardia sublevada: la identificación, en suma, del nosotros y el ellos, del otro mundo del que hablase Miquelarena, del contramundo. Nosotros: Cruzada, religiosidad, lealtad, valor, triunfo, heroísmo, martirio. Ellos: maldad, terror, oprobio, fealdad, excrementos.

\section{¡GUERRA SANTA!: LA CRUZADA COMO ESPACIO COMÚN}

Dada su importancia, más si cabe vista en términos de continuidades y discontinuidades entre temáticas políticas del fascismo prebélico y praxis del fascismo en guerra y posbélico, resulta fundamental arrancar la biografía de los orígenes del uso bélica de cruzada en los orígenes fundacionales del falangismo. Huelga decir que la apelación a la guerra y a la violencia se había convertido, en territorio común de la intransigencia política, y resulta útil situar a la extrema derecha revolucionaria en ese contexto en que la gloria de Falange «la iban cantando el plomo y la sangre por la tierra de los vientos de España ${ }^{6}$ para comprender mejor el grado de impregnación que lograría des-

\footnotetext{
5 ARRARÁS, 1938-1944.

${ }^{6}$ XIMÉNEZ DE SANDOVAL, 1941: 185.
} 
pués, en un contexto propicio de guerra y limpieza política. Falange y el fascismo representaban, pese a su escaso impacto cuantitativo, una opción política y cultural de fuerte relevancia cualitativa, caracterizada por la teoría y la praxis violenta. Para Gil Robles, el fascismo y la Falange se aparecían «a los ojos de muchas gentes conservadoras como la única tabla efectiva de salvación. Frente a una violencia, se escudaban en la violencia contraria» ${ }^{7}$. Para cerrar el paso al marxismo «no es voto lo que hace falta, sino pechos resueltos», diria José Antonio. El estilo falangista, recuerda González Calleja, sería un «ejemplo de la 'estetización de la política'», que sustituiría a la clase por la nación en tanto que sujeto revolucionario, y los derechos ciudadanos por los «valores comunes ritualizados» ${ }^{8}$, defendidos en su condición de monjes-soldados, «caballeros de la Hispanidad y cruzados de Dios $»^{9}$. Duros en la lucha pero generosos en la victoria ${ }^{10}$. Caballeros y cruzados.

«Se imponía el tiranicidio, la supresión del poder tiránico» ${ }^{11}$. Parcialmente derrotado y parcialmente triunfante, el golpe de Estado de julio del 36 terminó de definir al enemigo, y al amigo: coaguló a las diferentes fuerzas antirrepublicanas que, ya desde 1934 pero sobre todo desde febrero de 1936, venían practicando la más extrema heterofobia política, alimentando con una retórica eliminacionista la posibilidad - aunque en esto no estuvieran solos falangistas, alfonsinos, carlistas o militares intervencionistas - real y concreta de una guerra civil que acabase con la antiEspaña. Lo primero fue, tras el golpe de julio, identificar y legitimar las causas del Alzamiento Nacional, lo cual era como identificar a los enemigos: en principio, y según Núñez Seixas ${ }^{12}$, no a los de la religión, sino a los de la patria y la nación. A los «hijos de Rusia». Antes pues de la elaboración de unos mecanismos de identificación propios, hubieron de manejarse los repertorios heredados del pasado, desde una condición revolucionaria con rasgos de terror jacobino, hasta un sovietismo comprendido al modo de 1934 pero cuyo mito tenía ya una extensa duración ${ }^{13}$. El artículo de Ideal fechado el 5 de agosto de 1936 era más que elocuente: «Luchamos», decía, «contra los enemigos de la Patria que pretenden someterla a la miserable esclavitud de la Rusia soviética»; contra «los perseguidores de nuestra Religión»; contra «los incendiarios y bombardeadores de templos». En definitiva: «contra los malos españoles»: separatistas, liberticidas, saquea-

\footnotetext{
7 GIL ROBLES, 1968: 689.

8 GONZÁLEZ CALLEJA, 2011 y 71 (Madrid, 2008): 93.

${ }^{9}$ FE, 1-3-1934, p. 5, cit. en GONZÁLEZ CALLEJA, 71 (Madrid, 2008): 92.

${ }^{10}$ GALLEGO, 2005a y 2005b. MORENTE, 2013a.

${ }^{11}$ BALLESTEROS GALIBROIS, cit. en ÁLVAREZ ET AL., 2000: 169.

12 NÚÑEZ SEIXAS, 2006: 188.

${ }^{13}$ CRUZ, 1997.
} 
dores, mancilladores de la santidad del hogar, anticristianos, difamadores, asesinos y traidores «que se niegan a gritar ¡Viva España!» ${ }^{14}$.

El de la defensa de la nación española y católica habría sido el elemento cultural más fuertemente unificador de las diferentes tendencias políticas e ideológicas de la coalición vencedora, desde el nacionalcatolicismo al falangismo pasando por el tradicionalismo o el conservadurismo: todos tenían una idea de $s u$ España, y todas se definían en función del enemigo y se encaminaban a su expulsión de la comunidad nacional. De ahí, y de la cada vez más poderosa identificación de la sublevación con la causa católica, nacería el mitologema de la antiEspaña. Al principio hubo, pues, cierta polisemia. Sin embargo, poco tiempo, meses después, existía ya y operaba un macrorrelato integrador e identificador de gran fuerza narrativa y movilizadora, el de la Cruzada, con una explicación genérica de uso cotidiano que acabaría por convertirse en el leitmotiv trasversal y unificador en lo simbólico y que gozó de una fuerza y promoción intensísimas. En Las dos ciudades, del 30 de septiembre de 1936, Pla y Deniel escribiría aquello de que «Los comunistas y anarquistas son hijos de Caín, fratricidas, asesinos de los que cultivan la virtud». Y frente a ese mundo, «España tenía el derecho y el deber de rebelarse»: contra una «autoridad prostituida y usurpadora, antinacional y anticristiana, tiránica y delincuente», España no podía salvarse «por los caminos ordinarios». Tocaba imponer «la razón de las armas»: quien así escribía era el último obispo de Madrid, Leopoldo Eijo Garay ${ }^{15}$.

El relato de la Cruzada, enfatizado por la jerarquía católica, acabaría por engullir al de la salvación de la nación. O mejor, lo integraría: tal y como explicaría Franco en 1938 en su mensaje conmemorativo del segundo aniversario de la sublevación (en un ejemplo como pocos de síntesis y construcción de una lógica de causa y efecto), ofrecida a Rusia «la bolchevización de España», la contienda habría rebasado «los límites de lo nacional para convertirse en Cruzada, en la que se debate la suerte de Europa» ${ }^{16}$. Pero primero fue lo nacional. La propia perdición española y la voracidad bolchevique convirtieron la guerra en Cruzada: religiosa, y contra el comunismo ${ }^{17}$. Sin embargo, como concepto tampoco era del todo ajeno a la retórica fascista. Llamativa resulta, cuanto menos, la utilización falangista del concepto, al pedirle José Antonio a los suyos en marzo del 33, al poco del ascenso de Hitler al poder en Alemania, darle la mano «con soberbio aliento de castellanos de fe y hambrientos de conquista, a la otra mitad secular de la cristiandad europea, ergui-

${ }^{14}$ COBO Y ORTEGA, 2005: 138.

${ }^{15}$ Cit. en CASTRO ALBARRÁN, 1941: 397-398.

${ }^{16}$ Cit. en RODRÍGUEZ TARDUCHY, 1941: 55.

17 JULIÁ, 2004. MORENTE, 2013b. 
da en número de millones para la gran Cruzada» ${ }^{18}$. El Punto Noveno de la primera Falange hablaba de llamar «a una cruzada a cuantos españoles quieran el resurgimiento de una España grande, libre, justa y genuina» ${ }^{19}$. Y católico «de lucha, guerrero teólogo», el mismo José Antonio «nuestro Ausente, es católico práctico»: de los que profesaban «un catolicismo vital, con pretensiones de invadir todas las actividades humanas, así individuales como sociales», en la medida que «la religión no es solamente una serie de verdades, es también un sentido en el que ha de sumergirse la vida entera del hombre», se diría desde El Español en $1942^{20}$.

No menos eran los que llamaban, en 1936 pero antes del golpe de Estado, a la «Cruzada contrarrevolucionaria», como la Gaceta del Norte. Franco, en radio Tetuán el 25 de julio del 36, dejaría claro que «En esta cruzada, por una España grande, poderosa y respetada, no ha de faltar ninguno». Dos días después El Diario de León saldría ya con la primera valoración sobre el golpe de Estado: «El alzamiento nacional tiene el fondo de una cruzada contra los internacionalismos que pretendían llevar España por los caminos de perdición, de ruina, de muerte ${ }^{21}$. Pronto, muy pronto, un Franco aún no generalísimo verbalizaría una idea que, para Marrero, radicaba en el tradicionalismo carlista: la de estar ante «una guerra que reviste, cada día más, el carácter de Cruzada, de grandiosidad histórica y de lucha trascendental de pueblos y civilizaciones». Los combatientes eran «soldados de Dios» que no luchaban «contra otros hombres, sino contra el ateismo y el liberalismo», diría en 193722. También Mola, el 8 de agosto del 36 («cruzada contra la barbarie»), al pedir una oración por quienes dieron sus vidas «en la santa cruzada de salvar a la Patria» (15 de agosto de 1936), o cuando la denominaba, el 28 de enero siguiente, «santa cruzada contra el comunismo y la anarquía» optaría, sin demasiada carga semántica ni mayúsculas, por denominar así la lucha iniciada en el «Alzamiento Nacional» ${ }^{23}$.

Muy significativa, además, fue su presencia en los medios navarros tanto tradicionalistas como alfonsinos, que José Andrés-Gallego, siguiendo la línea de Palacio Atard, ha rastreado de manera minuciosa. "Cruzada magnífica», «cruzada gigantesca», «cruzada de salvación» no aludían, sin embargo, a un significado tan lleno y completo, sino más bien a un concepto vago de lucha justa, fondo «ideológico-religioso» ${ }^{24}$ de combatientes y sublevados, pero no

\footnotetext{
18 Cits. en BELTRÁN GÜELL, 1939a: 142-143.

${ }_{19}$ Cit. en ANDRÉS-GALLEGO, 1997: 16.

${ }^{20}$ Catolicismo y Falange, en El Español, n. 1, 31-10-1942, pp. 1 y 4.

${ }^{21}$ El Diario de León, 27-7-1936, p. 1, cit. en RODRÍGUEZ, 2003:143.

${ }^{22}$ Cit. en MARRERO, 1961: 165 y 167.

${ }^{23}$ Cits. en ANDRÉS-GALLEGO, 1997: 18.

24 ID.: 65.
} 
tanto porque sintetizase la reacción contra cinco años de persecución, como interpretaría un Palacio muy generoso con el Alzamiento, sino porque amalgamaba como ningún otro relato los mínimos comunes, la síntesis política e ideológica de los sublevados. De esos medios navarros pasaría a la circular del arzobispo de Santiago de Compostela Tomás Muniz: «la Cruzada que se ha levantado contra ellos es, patriótica sí, muy patriótica, pero fundamentalmente una Cruzada religiosa (...) se lucha por la fe de Cristo y por la libertad de los pueblos». Y a la del obispo de Pamplona, Marcelino Olaechea, llamando a la suscripción económica a la causa sublevada el 23 de agosto: «No es una guerra la que está librando, es una cruzada, y la Iglesia (...) no puede menos que poner cuanto tiene a favor de sus cruzados» ${ }^{25}$. Solo cinco días después, el Arzobispo de Valladolid laurearía el «honor a los mártires sin miedo y sin tacha, cruzados de Cristo y de España».

De igual manera suena el concepto en las palabras de Castro Albarrán cuando, al reseñar la connivencia en las trincheras sublevadas de la sangre «cristiana y sangre mora», afirmaba que «en esta extraña guerra, todo es cruzada auténticamente española» ${ }^{26}$. Y más pleno estará el significado en Las dos ciudades, la pastoral del 29 de septiembre de 1936 de Enrique Pla y Deniel: la de España era en sus formas externas una guerra civil, pero era, en realidad, «una cruzada» antes incluso de ser oficialmente así denominada. Sacrilegios, turbas anarquizantes, asesinatos e incendios precedían, como de hecho señalaba el obispo de Salamanca, al «apoyo oficial de la Iglesia». Una guerra religiosa cuya definición como Cruzada empezaría a tomar cuerpo en agosto de 1936, que tomaría carta de oficialidad desde la pastoral de Pla y Deniel, y que sería el leitmotiv de los mensajes episcopales a lo largo de toda la guerra ${ }^{27}$. En su primera pastoral sobre la guerra (El caso de España, de 23 de noviembre de 1936), Isidro Gomá la calificaría como una «guerra de principios (...) de una civilización contra otra», necesaria puesto que España estaba «ya casi en el fondo del abismo, y se la quiso salvar por la fuerza de la espada», y donde el «alma tártara, el genio del internacionalismo comunista» habría llevado a la patria al «choque con un temperamento forastero»:

si la contienda actual aparece como guerra puramente civil, porque es en el suelo español y por los mismos españoles donde se sostiene la lucha, en el fondo debe reconocerse en ella un espíritu de verdadera cruzada en pro de la religión católica, cuya savia ha vivificado durante siglos la historia de España y ha constituido como la médula de su organización y de su vida.

${ }^{25}$ El Pensamiento Navarro, 24-8-1936, cit. en ÁlvAREZ BOLADO, 1995: 42.

${ }^{26}$ CASTRO ALBARRÁN, 1938b: 35-36.

27 BOTTI, 1992. DI FEBO, 2002. 
Para Olmedo, la guerra era «ante todo religiosa, la más religiosa de todas las españolas, que es decir de todas las guerras habidas y por haber» ${ }^{28}$. Era ya una guerra religiosa, sentido sin el cual quedaba «enervada»: patria y religión serían, para el primado de la iglesia católica en España, los resortes de la movilización en masa de los combatientes ${ }^{29}$. El proceso era, con todas las precauciones que han de tenerse a la hora de hablar de algo tan pluridireccional y huidizo como la construcción de los relatos, el de la transformación de una cruzada en la Cruzada. Es decir: el trayecto entre una cierta pluralidad de significados entre los que el de cruzada era uno más, significativo pero no único, hacia la elevación de la causa sublevada a rango místico, según lo cual la Cruzada sería el «punto final a una secuencia histórica» de declive y resurgimiento del «destino espiritual» de España ${ }^{30}$. Según diría el Arzobispo de Córdoba en diciembre de 1936, «El Pueblo español se ha puesto en pie para la Cruzada más heroica que registra la Historia» ${ }^{31}$. Y como recordaría Castro Albarrán en su reelaboración de 1941 de su Derecho a la rebeldía de 1935 bajo el título de El Derecho al Alzamiento, la del 36 era la última de las cruzadas, la que más había evidenciado el alma de España, «refractaria a narcóticos sumisionistas $»^{32}$.

La célebre carta colectiva firmada por Gomá en 1937 no incluía la noción de cruzada. No la usaron ni Ratti ni Pacelli — respectivamente Pío XI y XII. Como recuerda Hilari Raguer (2001), tanto Gomá como Pla i Deniel habían empleado ya el concepto, pero no fue después recogido en el documento que había de fijar la postura oficial de la Iglesia. No era necesario. La Cruzada como relato endógeno en la iglesia católica española provenía, en su utilización bélica, del poder civil y militar. La carta colectiva, sin embargo, sancionaba elementos mucho más prosaicos que la denominación de la guerra. Así, los obispos firmantes, «en descargo de tantas víctimas, alucinadas por 'doctrinas demonios'» se congratulaban de que

«al morir, sancionados por la ley, nuestros comunistas se han reconciliado en su inmensa mayoría con el Dios de sus padres. En Mallorca han muerto impenitentes sólo un dos por ciento; en las regiones del sur no más de un veinte por ciento, y en las del norte no llegan tal vez al diez por ciento. Es prueba del engaño de que ha sido víctima nuestro pueblo».

Puede que se tratase de los delirios de un exaltado, pero a pesar de cuestionar los asesinatos de «inocentes» como «acto[s] crimilal[es]», el jesuita

\footnotetext{
28 OLMEDO, 1938: 18.

${ }^{29}$ GOMÁ, 1940: 23. ID.: 30, 38, 25.

${ }^{30}$ COBO, 71 (Madrid, 2008): 144.

${ }^{31}$ Cit. en CASTRO ALBARRÁN, 1938a: 105.

${ }^{32}$ CASTRO ALBARRÁN, 1941: 380.
} 
Fernando Huidobro consideraba merecida la muerte de «los guías y promotores conscientes de un movimiento como el comunista ${ }^{33}$.

Era necesario, escribía en 1937 desde Buenos Aires el presbítero tomista Julio Meinvielle, que España «conociese el abismo abominable de degradación que señala la barbarie comunista para que despertase, en un puñado de valientes, el sentido de su grandeza». La República habría servido, en su «barbarie, para devolver en un instante a España el sentido de su propia vida. España es católica a machamartillo o España sucumbe en la barbarie comunista». España era «de Cristo o del Anticristo. España o AntiEspaña», y por eso las «milicias intrépidas» se habían lanzado a la «reconquista» guiados por caudillo «predestinado» suscitado por dios, a la cabeza de «contingentes moros que ambicionaban formar parte de esta heroica cruzada contra el comunismo ateo que querían implantar los judíos», y cuya lucha de «un puñado de valientes» había animado a la lucha «entre el pueblo auténtico, y el pueblo falseado; entre el pueblo y la chusma» para la «reconquista palmo a palmo del propio suelo de las garras de la chusma roja». La guerra «es una guerra heroi$c a$ es también una guerra santa»:

Si la lucha se desarrolla en el plano teológico ¿qué carácter debía revestir en uno y otro bando? Pues de un lado debía de ser de Cristo, cristiana, y del otro del Anticristo, anticristiana; de un lado santa y del otro satánica. Y he aquí que frente al aspecto desolador de un pueblo empeñado en triturar iglesias, en martirizar ministros de Dios, en profanar religiosas; por el otro, se ve a un pueblo desbordado de fe que no puede lanzarse a la lucha sino después de reconfortarse con el sagrado cuerpo de Cristo y al grito de viva Cristo Rey ${ }^{34}$.

La guerra sería santa, además, porque de España habría de extenderse al resto del globo. Así, tras varios siglos de «vergonzosa apostasía de la Europa cristiana», la guerra comenzaría la «reconquista cristiana del mundo apóstata $\aleph^{35}$. En otros tiempos, recordaba en 1939 Justo Garrán, la Europa cristiana luchaba contra «árabes, tártaros o turcos», pero hoy «el enemigo es interior (...) una infección extensa en el orden de las ideas ${ }^{36}$. España recobraría con la Guerra Santa «el sentido espiritual de imperio cristiano: o sea adquirirá voluntad de proyectar en las naciones la influencia saludable de Cristo. Será una conquista espiritual de almas»: almas musulmanas, almas en las antiguas colonias de América y Asia, y almas, por fin, europeas. Primero,

\footnotetext{
${ }^{33}$ Cit. en RAGUER, 2001: 192.

${ }^{34}$ MEINVIELLE, 1937: 30-37.

35 MEINVIELLE, 1937: 40.

${ }^{36}$ GARRÁN, 1939: 6.
} 
junto a las potencias fascistas o semifascistas de Europa para dar término a la tarea de quebrar la cabeza del monstruo comunista... y más tarde, brazo derecho de la Cristiandad, pondrá término a la Prepotencia babilónica de los modernos imperios paganos, concentrada sobre todo en Alemania ${ }^{37}$.

La de Meinvielle era una disputa abierta contra Jacques Maritain sobre la cuestión de la guerra santa y por la extensión de la noción de Cruzada y su identificación con la clásica de Hispanidad. Eso, evidentemente, le dotaba de algunos matices diferentes vista desde Sudamérica, que a juzgar por algunos retazos de discurso podría considerarse no tan minoritaria. Para el editorialista de $A B C$ en Sevilla, en día de la Fiesta de la Raza de 1937, Franco era para América el «continuador de la Historia gloriosa de la Patria. Y si la Cruzada viene a restaurar el destino Imperial de España, con la Cruzada han de hallarse compenetrados $»^{38}$. Las naciones americanas, diría, se habrían dado cuenta de la falsedad de la «existencia de dos España [sic]», y habrían sabido ser «leales a la progenie inmortal. La voz de la sangre no podía dimitir sus dictados» ${ }^{39}$. Y sangre, mucha, fue la que regó los cimientos de la Nueva España. En palabras de quien, de todos los miembros del grupo de Acción Española, mejor simbolizaría el tránsito hacia el caudillaje totalitario ${ }^{40}$ basado en la experiencia fundadora de la guerra santa: «En una época de tremenda crisis, encarnando la Voluntad de Dios, [Franco] salva a un país - España-, a una civilización - Europa-, a la misma Obra de Dios en la tierra - la Cristian$\operatorname{dad} »^{41}$. Defender, además, a los católicos frente a la violencia sería una base fundamental de legitimidad que equilibraría y daría contenido al Alzamiento. «No podemos olvidar», señalaría en 1939 Eloy Montero «que acabamos de realizar una Cruzada y que el nuevo Estado es fruto de esa Cruzada misma»; que con:

sus Crucifijos, medallas y escapularios sobre el pecho fueron al campo nuestros soldados; que ha habido millares de mártires, víctimas de la horda por profesar su fe, y que falangistas, requetés y soldados dieron su vida en las trincheras por Dios y por España ${ }^{42}$.

«¡Bienvenida sañuda persecución a la doctrina de Cristo», escribía en 1937 Francisco de Armas, «tú has templado las almas en el dolor, tú has fortalecido

\footnotetext{
37 MEINVIELLE, 1937: 40-42.

${ }_{38} \mathrm{Al}$ respecto, GALLEGO, 2011.

$39 A B C$ (Sevilla), 12-10-1937, pp. 3-9, 15, 17.

${ }^{40}$ MORODO, 1985: 183.

41 PEMARTÍN, 1937: 89. TELLO, 1984.

42 MONTERO, 1939: 247-304, cit. en GALLEGO, 2014.
} 
y has estampado, con cuño indeleble, la fe católica en nuestros corazones!» ${ }^{43}$. El propio Beneyto señalaría que la «legitimación del Alzamiento» venía por la «defensa de los católicos ultrajados (...) la oposición a los sacrificios de víctimas inocentes y de hombres inculpables», mirando sobre todo a los «crímenes perpetrados por los rojos» ${ }^{44}$ — si bien, para 1939, ello sirviese no para restaurar el orden, sino para crear uno nuevo. No había problemas ideológicos en ello, al menos aparentemente. En su deseo de unidad, el jefe de la censura afirmaría que «Falange es católica (...) el catolicismo es factor importante de nuestra Unidad, y ha de seguir vivificándola junto al amor a la Patria española $\rangle^{45}$. La misma idea defendía el discurso emanado desde Pamplona por el sacerdote falangista Fermín Yzurdiaga sobre el profundo catolicismo de Falange, algo por otro lado presente en el pensamiento político del fascismo español ya desde los textos doctrinarios de José Antonio. Y coincidía Castro Albarrán: «de Falange Española, organización, programa, movimiento, yo tengo que afirmar que es católica» ${ }^{46}$.

Pero además del propio contenido teórico y programático, lo que terminaría de definir el espacio común que supuso la Cruzada fue el contexto mismo de guerra civil. Pronto, en forma de narraciones de asesinatos de sacerdotes, de violaciones de monjas, de incendios de iglesias y de profanaciones de cementerios, llegaría a la retaguardia sublevada, impactaría en sus medios de producción de relato, simplificaría todos los debates existentes y construiría con mayor fuerza si cabe una narración específica, una identidad propia hecha de negación y alienación de la del enemigo, la noticia de la forma más terrible, abyecta, infrahumana y espantosa del terror rojo: la furia anticlerical. La violencia sacrofóbica sería, de hecho, la apoyatura sin la cual la Cruzada carecería de sentido. «La guerra hubiera sido, necesariamente, religiosa, porque lo han querido ellos. Porque ellos son los que han encaminado la guerra directamente contra la religión ${ }^{47}$, diría Castro Albarrán. Por ese motivo, la literatura martirológica fue inmensa, y probablemente se encuentre entre las más impactantes a nivel popular de cuantas nutrieron el relato de la Cruzada, al menos a juzgar por sus pervivencias. Como reconocería el obispo de Astorga en noviembre de 1936, era «el relato de las monstruosidades que nuestros enemigos van cometiendo en los pueblos en que dominan por algunas horas», las historias de los «asesinatos de obispos, sacerdotes, religiosos y fieles cristianos», los «incendios de iglesias, la profanación de santuarios» los que de-

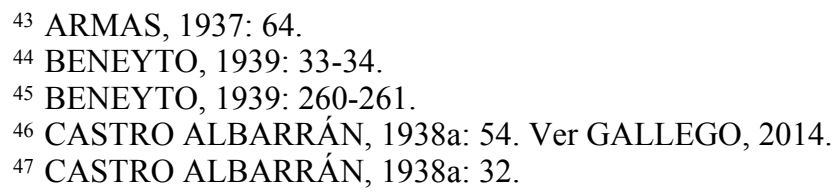


mostraban la necesidad de la Cruzada ${ }^{48}$. En 1937 aparecerá, publicada en Buenos Aires, la obra de Joan Estelrich La persecución religiosa en España y, en 1938 y 1940, las de Aniceto de Castro Albarrán o Lluis Carreras, puntales para la narración de las «atrocidades» revolucionarias que acabarían recogidas en el Santuario de la Gran Promesa de Valladolid, y padres, en buena medida, de una lectura de la violencia republicana en clave religiosa y no política, lo cual no quiere decir que su uso no fuese político ${ }^{49}$. La extensa obra del segundo ha merecido más de un comentario ${ }^{50}$ pero tal vez siga difuminada su importancia en la construcción de una imagen común del martirologio, de las víctimas de la «persecución religiosa» y de sus victimarios.

Este es el cortejo fue el título del libro publicado por Castro Albarrán en 1938. Héroes y mártires de la Cruzada española era el subtítulo. En él, la primera y más importante víctima del martirio había sido España: «Toda ha sido martirizada» ${ }^{51}$, pero el relato de la «barbarie roja», pormenorizado y literario, recorre pueblos, cárceles, sacristías y cementerios. Este es el cortejo, sin embargo, no se construía sobre una visión global deshumanizada y heterófoba del enemigo, y por tanto es, en parte, una excepción. Hay muertes atroces, violencia descontextualizada, masas que lanzan vivas a Rusia, una valentía temeraria y un desprecio fanático a la muerte por parte de los «mártires». Sobra retórica, no existe el análisis y, por supuesto, solamente hay relatos de los muertos por el «terror rojo». Pero, en tanto que pieza literaria, es muy superior a la literatura martirológica de guerra y posguerra pues, pese a compartir unos excesos retóricos utilizados incluso en nuestros días (la «borrachera de sangre» de Ronda) y contener evidentes exageraciones, en muchos momentos transmite una afectación aparentemente sincera y verídica. Cuando explica las ejecuciones al borde de un pozo en Hornachuelos, Córdoba, relata cómo «llegaba el sentenciado hasta la boca de esta sima y le hacían colocarse sobre el borde de piedra. Un pelotón de escopeteros disparaba sobre él (...) como la boca del pozo es estrecha, los infelices, antes de hundirse en el abismo, caían de golpe contra el lado opuesto del brocal... Días más tarde se veían en las paredes del pozo los regueros de sangre» ${ }^{52}$.

El cortejo de Albarrán no era solamente de religiosos. Lo integraban desde España como nación hasta Calvo Sotelo o Víctor Pradera, los militares cuya sublevación abortaron en Bilbao, los voluntarios que, como el duque de Fernán Núñez, habían cambiado una vida «amable y suave» en retaguardia por

48 Cit. en RODRÍGUEZ, 2003: 150.

49 ESTELRICH, 1937. CASTRO ALBARRÁN, 1938a, 1938b y 1940. CARRERAS, 1938. AYAPE, 1939.

50 ROBLEDO, 2007: 327-342.

${ }^{51}$ CASTRO ALBARRÁN, 1938b: 20.

52 CASTRO ALBARRÁN, 1938b: 158-159. 
«el primer deber que tenemos todos los hombres, después de servir a Dios, que es la patria», o como el marqués de Monasterio, Ricardo Martorell, que de entre «todos los amores (...) el amor más fuerte era el amor a España» ${ }^{53}$. Lo integraba Luis Moscardó, el hijo del defensor del Alcázar ${ }^{54}$. Lo integraban las «palmas y coronas sacerdotales». Y lo integraba

Dios, (...) el Capitán de los héroes y (...) cabeza de todos nuestros mártires. Con los héroes ha entrado en acción de guerra y ha tomado parte en las batallas. Y ha sido bombardeado y ha caído prisionero y le han fusilado (...) Dios forma en nuestro Cortejo ${ }^{55}$.

No lo integraban, sin embargo, caídos de lo que Gomá llamaba «tendencias forasteras al espíritu nacional y cristiano», palabras donde cabe leer determinadas actitudes falangistas del desagrado del Primado de España. Ni Onésimo Redondo, ni Ruiz de Alda, ni Ramiro Ledesma, ni José Antonio Primo de Rivera fueron llamados por el magistral salmantino a formar parte del cortejo salvador. Pese a que eso no le servía para explicar por qué Franco había elegido precisamente a Falange y al Carlismo para la organización del Nuevo Estado, Castro Albarrán señalaría, en 1938, que era lo «nacional», y por tanto lo religioso, el paraguas abierto bajo el cual se refugiaban las diferentes identidades políticas unidas en el Movimiento. No era, pues, «ni guerra civil, ni mera reacción fascista, ni lucha de clases»:

El fascismo español había también formado su cruz con el yugo y las flechas de los Reyes más Católicos y, al enviar a sus falangistas a dondequiera que llamaba el aullido de la guerra, les había también escudado el pecho con escudos de cruces y de medallas. Falange Española era Falange de Cruzados.

Nada, pues, que ver con «fascismos panteístas y hegelianos»56: Guerra Santa y Cruzada de Liberación, voluntariamente aceptada por todos. No había de tal modo más necesidad de legitimación que el 18 de julio, el levantamiento al lado de un Dios que «había mandado a la victoria que fuese siempre con nosotros», contra una República del terror y la violencia, de «masonería y marxismo» ${ }^{57}$. Una victoria enviada por Dios mediante un Caudillo salvador. Para todos, falangistas y eclesiales, fascistas y fascistizados, Franco aunaría a la verdadera España en combate, en Guerra de salvación por la fe, la inde-

\footnotetext{
${ }^{53}$ CASTRO ALBARRÁN, 1938b: 100-101 y 111.

${ }^{54}$ CASTRO ALBARRÁN, 1938b: 209.

${ }^{55}$ CASTRO ALBARRÁN, 1938b: 289.

${ }^{56}$ CASTRO ALBARRÁN, 1938a: 28.

${ }^{57}$ FERNÁNDEZ ALMAGRO, 1940: 10.
} 
pendencia y la tradición ${ }^{58}$, dotándola de una causa movilizadora y exaltadora de anhelos patrióticos y de victoria. Y más todavía desde la unificación en 1937 y la creación, desde elementos previos, del nuevo partido único fascista. Frente a ella, el Ejército salvador y Franco, su cabeza visible, como reconocería José Pemartín en 1938: más que «la fuerza armada al servicio de una causa», era «algo esencialmente nacional, es el compendio de las virtudes ciudadanas elevadas de tónica a un grado supremo por el concepto del deber, el desprecio de la vida». Por eso, «el Ejército no sólo nos ha salvado y nos está salvando en la guerra, sino que nos ha de salvar y ha de ser la médula de nuestra paz victoriosa». Por eso,

por encima de toda su privilegiada inteligencia y sus grandes virtudes y capacidades de estratega, de político y de Caudillo, todos los españoles se sentirán siempre atraídos por la figura de Franco, se sentirán siempre adecuada y honrosísimamente mandados por él, porque verán en él dibujarse la figura más gallarda, más simpática, de más autoridad moral, de mayor nobleza que existe: El Caballero sin miedo y sin tacha, el Jefe heroico y laureado del Tercio español ${ }^{59}$.

Seguramente la España de los franquistas fue bastante más polisémica que la homogeneidad historiográficamente más o menos aceptada. Sin embargo, lo que parece bastante monolítico es la visión que esos vencedores, cada uno con su idea de España, tenían de la antiEspaña, y de los modos de actuación frente a ella. El jesuita Joaquín Azpiazu la llamaría «guerra religiosa, en la que se quiere barrer la irreligión bolchevique o la barbarie comunista y atea (...) Así puede orlar la muerte por la Patria la aureola de mártir; porque murió por la Patria, pero mirando por encima de ella a Dios, y sólo a Dios» ${ }^{60}$. Vencido el régimen republicano, tocaba elevar las banderas del triunfo, cantar las gestas heroicas, construir una «comunidad ideológica» ${ }^{61}$ alrededor de una narrativa estatal. El éxito de la noción de Cruzada fue pues gigantesco, tanto por su vinculación con elementos míticos, identidades fuertes y pasados heroicos como por su difusión entre las diferentes fuerzas separadas entre sí antes del 18 de julio, y unidas después. Las enfrentadas en la guerra fueron, en todo caso, identidades totalizantes para una guerra total: occidente contra oriente, España contra el invasor, España contra la antiEspaña. Como señalaría el editorialista de $A B C$ (Sevilla) en 1937,

No son dos España [sic] en lucha, sino España y la antiEspaña. Sólo hay una España, inmortal y única. La de Sagunto y la de Numancia. La que en Covadonga

\footnotetext{
58 COSSÍO, 1937.

59 PEMARTÍN, 1938: 18-19.

${ }^{60}$ AZPIAZU, 1938: 25 y 30, cit. en GALLEGO, 2014.

${ }^{61}$ RICHARDS, 2006: 180. MORENTE, 2011 y 2013 a.
} 
y en Lepanto, al salvar a la civilización cristiana, salvó a Europa, y la que, ahora también, unida y enfervorizada en pos del Caudillo Franco, se opone victoriosa a las rudas embestidas de las hordas sin Dios y sin Patria.

Era pues urgente la españolización, re-nacionalización, reeducación y recatolización de la población en clave ultranacionalista. De ahí el éxito de la narrativa de la Cruzada. Muchas voces se sumaron a esta «obra de reconstrucción nacional», que es como Olmedo, consciente de las consabidas reticencias de la jerarquía eclesiástica para con algunas caracterizaciones ideológicas del falangismo, entendía la redacción de su libro El sentido de la Guerra Española en 1938, pese a que su exaltación católica de la guerra no tuviese pocos problemas con la censura falangista en Salamanca ${ }^{62}$. Este relato, esta interpretación global de la guerra, vino en cualquier caso a reforzar una cosmovisión intelectual hecha de dicotomías binarias y maniqueas (España/antiEspaña, vencedores/vencidos, patriotas/traidores o, en definitiva, buenos/malo) ${ }^{63}$. Por su sencillez y aplicabilidad, y por substanciar en buena medida lo que la guerra venía a ser para buena parte de la población en la retaguardia sublevada - movilización, propaganda, noticias de la retaguardia enemiga - , se convirtió rápidamente en relato y narración preponderante, cuyo fin último era tanto la legitimación del poder de las fuerzas antirrepublicanas como la diabolización extrema del enemigo, caricaturizado y sometido a la más radical alterización, siempre con el objetivo último de hacer más aceptable su eliminación. Pocas fuentes permiten afirmarlo con más fuerza que la literatura martirológica de guerra y posguerra.

\section{EL HOLOCAUSTO DE NUESTROS MÁRTIRES: LA LITERATURA DE LA CRUZADA}

Historiador y falangista, para Emilio Rodríguez Tarduchy la guerra había amalgamado a la verdadera España frente a la antiEspaña y limado las aristas identitarias, al poner al país en pos de una meta común contra un enemigo concreto y definido, el rojo, la negación misma del ser de España. Ese sería el camino que habría de seguirse para que no se traicionase el «sagrado mandato de nuestros muertos» ${ }^{64}$. En el contexto de guerra santa, nacería una literatura caracterizada por la exaltación de los valores de los sublevados y la denigración extrema del enemigo. El elemento narrativo que fue imponiéndose sobre esa cultura de guerra para legitimar los actos de violencia no fue otro que el de la proyección hacia fuera, hacia el enemigo, de los actos de depravación,

${ }^{62}$ ALTED, 1984.

${ }^{63}$ LEDESMA Y RODRIGO, 63 (Madrid, 2006).

${ }^{64}$ ARRARÁS, en RODRÍGUEZ TARDUCHY, 1941: III. 
ilegalidad, tortura, sadismo. No cabe sorprenderse, así, del éxito que ya durante el conflicto armado - que se trasladaría con mayor fuerza si cabe a la posguerra - tuvo tanto la exaltación de los caídos como la brutalización del enemigo. Se trataba, de hecho, de políticas que se retroalimentaban. Durante los meses del Alzamiento, y en los de su transición hacia una guerra civil, en la retaguardia franquista se impondría como único recuerdo posible el recuerdo de una violencia solamente interpretable en clave de terror rojo. Así, Beltrán Güell resumiría en 1939:

cómo empezó la gran Cruzada nacional emprendida para arrancar a nuestra querida España de las garras de la bestia soviética, que habían apadrinado los hierofantes españoles de la pseudo-democracia, pactada con el robo y el asesinato que constituyen la sustancia de la novísima escuela rusa.

Por ese motivo, «el alma del país estaba profundamente envenenada» ${ }^{65}$. La antiEspaña, soviética y de los intelectuales, era el cáncer destructor de la verdadera nación ${ }^{66}$. Para Enrique Suñén, era urgente «practicar una extirpación a fondo de nuestros enemigos, de esos intelectuales, en primera línea, productores de la catástrofe» ${ }^{67}$, o de «mandamás» de cada pueblo, árbitro de los «paseos» trágicos de familias enteras, por haber asistido a una representación de «El Divino Impaciente» o porque uno de ellos hablase el alemán, el italiano o el portugués, «o les habían visto salir de Misa». Para Beltrán Güell, lo visto en la «zona roja (...) no se ha visto ni aun durante el Terror o la Commune franceses, ni en el primer período terrible de la Revolución Rusa» ${ }^{68}$. En zona roja todo era «desorden, crímenes, persecuciones, angustia, robos y hambre»; en la nacional, «justicia, orden, bienestar, tranquilidad y respeto mutuo» ${ }^{69}$. Justicia, bienestar y, como no podía ser de otra manera tratándose de una literatura de retaguardia, heroísmo. Frente a los rojos, se situarían los héroes, los victoriosos, los puros. Los muertos, claro está, pero también los vivos, y entre estos últimos, los supervivientes. La literatura de guerra escrita por huidos de la zona roja, supervivientes a cautiverios extremos, a checas inhumanas o a torturas execrables se hizo, en buena lógica, habitual y casi un género propio ya desde la misma contienda bélica ${ }^{70}$. La condición de víctima, de hecho, se convirtió en la retaguardia sublevada en enseña y factor de superioridad moral, política y social. Eran los «mejores» en una España de «buenos de verdad» $»^{71}$.

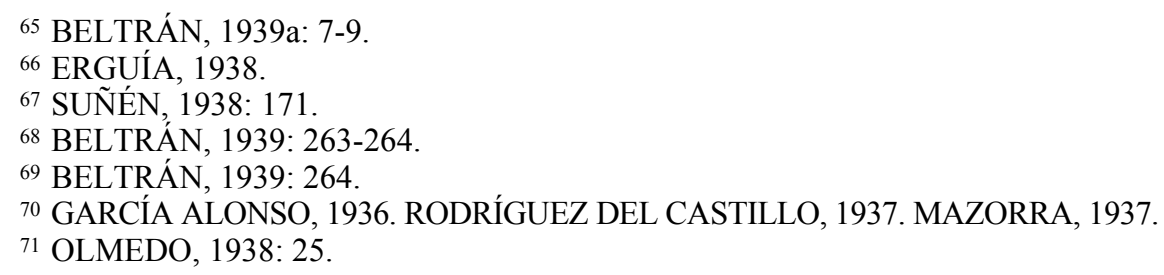


Las narraciones de y sobre las víctimas y los testigos del «terror rojo» ocuparon un espacio central, en periódicos y literatura ${ }^{72}$. La evocación de un mundo enemigo, parasitario, sin escrúpulos y sin límites a la violencia construiría, de tal modo, una imagen de un sujeto colectivo, el «rojo», el «bolchevique», ficticia e imaginaria, pero necesaria para la experimentación de la realidad «en la apariencia de ese contramundo» ${ }^{73}$. Ello formaba parte de una interpretación global del conflicto en la cual los sublevados estarían instalados en la razón, por mor de la bajeza, insalubridad y extrañamiento del enemigo. Uno de sus más destacados cultivadores sería, ya en 1937, Pérez de Olaguer en El terror rojo en Cataluña, en la que daría cuenta del «desbordamiento soviético», las «hordas sacrílegas» bajo el mando de Satanás ${ }^{74}$. En Madrid, mientras tanto, rugía la «bestia apocalíptica» inundándolo todo «con su baba inmunda» ${ }^{75}$, con su «tufillo» marxista, de «mujerzuelas y masones, escoria de la carne y del espíritu» ${ }^{76}$. Un tufo reconocible: era posible distinguir, según el periodista granadino Julio Moreno Dávila, «a un marxista y aun seguir su rastro con un olfato poco ejercitado» ${ }^{77}$.

Agustín de Foxá, en su celebérrima (y posiblemente más importante pieza literaria de entre los libros sobre la retaguardia revolucionaria vista desde sus enemigos) Madrid de corte a checa, evidenciaría de manera gráfica la distancia metafórica que se ponía de manifiesto con la supuesta ocupación del centro de la capital y de su zona noble por la «hez de los fracasados, los torpes, los enfermos, los feos». También los intelectuales fascistas tenían que contribuir al desprecio, la alienación y la desempatía para con los habitantes de la zona roja. El artículo dedicado al mes de julio por Agustín de Foxá en el número 17 de Vértice abundaba en esta línea, rezumando tanto asco por los extranjeros de las Brigadas Internacionales («toda la hez de los puertos mediterráneos, de las razas infectas, aperas erguidas de la animalidad, negros, chinos soviéticos, indios mejicanos, el detritus de los barrios chinos desde Liverpool a Marsella») como por la «chusma» española, los «milicianos entristecidos» de «literatura pornográfica a treinta céntimos». «Los poceros, los que recogen la basura, los limpiabotas, los chóferes de taxis, asesinaron a los oficiales - honor y fe- en el Cuartel de la Montaña ${ }^{78}$.

72 MARTÍNEZ CACHERO, 2009. GARCÍA, 76 (Madrid, 2009): 154-155.

73 WINCKLER, 1979: 119.

${ }^{74}$ Se convertiría, de hecho, en todo un experto del género, con tres libros diferentes sobre tres zonas distintas (Cataluña, Andalucía y La Montaña): PÉREZ DE OLAGUER, 1937, 1938 y 1939.

75 CORDONIE, 1939: 25.

${ }^{76}$ Cit. en DEL ARCO, 2007: 50.

77 Cit. en HERNÁNDEZ BURGOS, 2011: 93.

${ }^{78}$ Cit. en ALBERT, 2011: 175. 
Mostrar al enemigo como una turba sucia, maloliente y degenerada, una masa informe, violenta y aprovechada, una «plebe exaltada», fue un elemento común de buena parte de los libros que, publicados en Burgos, Valladolid, Sevilla o Zaragoza, describían ese otro mundo: el Madrid «terrible de odio», rojo, bajo el terror o bajo las hordas ${ }^{79}$; la Barcelona de la tragedia roja. Para Tomás Borrás, en su célebre Checas de Madrid, los madrileños habían sido sustituidos por las gentes de los suburbios, «marea de la miseria y el andrajo», que «vomitaban en el lujoso centro de la capital sus heces turbias» ${ }^{80}$. Madrid, «que resurge de entre sus cenizas», estaba sumida en las tinieblas, atenazada por el terror comunista, por las brigadas de información, por los García Atadell — «inteligente, sádico y refinado... un marxista perfecto» ${ }^{81}$-, su escuadrilla del amanecer, su odio de clase y su checa de Bellas Artes ${ }^{82}$.

No estaban solos Foxá y Borrás. Para Jesús Rodríguez del Castillo ${ }^{83}$, en las cárceles rojas concurrían «mujeres de pelos revueltos, de caras afiladas en el odio y en la insaciabilidad» con individuos de «aspecto típicamente criminal y malvado de sus caras angulosas, patibularias y lombrosianas». Era el gran día de la revancha «de los débiles contra los fuertes, de los enfermos contra los sanos, de los brutos contra los listos» ${ }^{84}$. Cuando Félix Ros, escritor falangista detenido en Barcelona, describa a los guardianes de su cautiverio en la checa de Vallmajor, lo hará en términos muy gráficos y explícitos de degeneración, degradación y enfermedad, pero siempre con un trasfondo moral: la enfermedad y la degradación no eran elementos ajenos sino el resultado de acciones y voluntades. Los rojos de la checa eran seres supurantes, malolientes, sarnosos, llenos de enfermedades venéreas: leprosos como Calleja, sifilíticos y tracomáticos como Julio, sádicos como Campillo, tuberculosos como Ramón, paraepilépticos como Adán, afectados de ginecomastia como Meana, hematúricos como Arias - pese a que, según Ros, orinar sangre era una «especie de blasón común a todos los agentes del SIM»-, sarnosos como Cuadrado ${ }^{85}$. Enfermedades todas ellas de naturaleza específica: no es que solamente los rojos las tuvieran, es que solo ellos podían tenerlas. Y el por qué solamente podía explicarse en términos de determinismo y predisposición que, evidentemente, debían por fuerza retrotraerse a momentos anteriores y, como es de sobra conocido, especialmente a la República. Esa patologización de la conducta

79 GUILLÉN, 1937. SANABRIA, 1938. PUIG, 1937. FERNÁNDEZ ARIAS, 1937 y

1938. FONTERIZ, 1937. FORONDA, 1937.

${ }^{80}$ BORRÁS, 1939: 28.

${ }^{81}$ FOXÁ, 1938: 373.

82 BERDIÓN, 1937: 57. MIQUELARENA, 1937.

${ }^{83}$ RODRÍGUEZ DEL CASTILLO, 1938: 84, cit. en CAZORLA, 2007.

${ }^{84}$ FOXÁ, 1938: 294.

85 ROS, 1939: 39-45. 
enemiga atravesó las letras de cuantos explicaron su guerra a su presente y su futuro. Se auguraba, sin ir más lejos, el Cardenal Gomá, prologando al año y medio de la «terrible contienda» y el «Movimiento Nacional» la Guerra Santa de Castro Albarrán, que no permitiese dios, «que hizo sanables a las naciones», que «después de haber sajado el bisturí hasta la entraña viva de España, se infeccione la herida por falta de asepsia — ison tantos los microbios del ambiente! $\longrightarrow{ }^{86}$. La Cruzada como remedio: enfermedad, bisturí, y sanación; pecado, castigo y redención.

Esta percepción denigratoria, esta construcción odiosa del enemigo echaba sus raíces en el tiempo de construcción de las identidades colectivas que colisionarían durante la guerra. Y, en particular, el tiempo republicano en tanto que dinamizador colectivo y marco de oportunidades políticas para sujetos colectivos. Es evidente en el caso de la percepción de la mujer: «Mujeres jóvenes de caras pálidas, ojos hundidos y labios rojos por el carmín gesticulan, blasfeman (...) Mujeres de porte hombruno con las huellas del vicio y de la crueldad en sus caras (...) glorifican el crimen, entregándose a las más brutales libaciones ${ }^{87}$. «Mujeres sin educación y sin instintos de feminidad, posesas de una mal contenida fiebre sexual, que creían llegado el momento de entregarse a la libre alucinación de la carne», según Romero Marchent. «Mujeres rojas, de falda en jirones, desgreñadas, con el pecho al aire, asquerosas y sucias, como monstruos fantásticos», según Foronda ${ }^{88}$. Toda la literatura denigratoria del enemigo, de Borrás a Foxá, de Panés a Arrarás, parte de iguales premisas y traza similares descripciones. Términos como «mujerzuelas», «tiorras», «prostitutas» no fueron invención de la propaganda sublevada ${ }^{89}$. Sin embargo, la movilización y la guerra multiplicaron exponencialmente su utilización.

También la del contrajemplo: los mártires. «Por los siglos de los siglos», inmóviles, indestructibles, «como nada puede hacer que desaparezca la mancha de sangre en las manos de Caín». Las víctimas del terror rojo, los caídos por España simbolizaban, para Wenceslao Fernández Florez (1939), el eje gravitacional del discurso legitimador de la Nueva España. Las fotografías y nombres de los asesinados, ejecutados por el «terror rojo» y muertos en batalla aparecían constantemente en periódicos y pasquines. Y su recuerdo se invocaba en prácticamente cualquier acto público en la posguerra. De las políticas enfocadas hacia la articulación y consecución de un consenso activo en torno al Régimen, a su Caudillo y a los valores que representaban, ninguna tuvo, posiblemente, tanta importancia cotidiana como el culto a la memoria

\footnotetext{
${ }^{86}$ CASTRO ALBARRÁN, 1938a: 10.

87 PANÉS, 1941: 19-20.

${ }^{88}$ Cits. en GARCÍA, 76 (Madrid, 2009).

${ }^{89}$ ORTEGA, 2011.
} 
de los caídos. En el decreto de 1938 que señalaba el 20 de noviembre como día de luto nacional, se recordaba que en cada parroquia habría de inscribirse el nombre de los caídos por Dios y por España, «ya en la presente Cruzada, ya víctimas de la revolución marxista».

En la posguerra, la política de memoria de la España de Franco fue el reflejo la unión de diferentes tradiciones políticas y simbólicas, coaguladas por la Guerra Civil, unificadoras y homogeneizadoras. De hecho, pese a que no fuesen exactamente lo mismo por la naturaleza de sus muertes, también la muerte en combate, la de los caídos, fue «recordada y celebrada como un martirio $»^{90}$. La posguerra fue prolífica en literatura bélica, de excombatiente, de camaradería de trinchera. Partes de guerra, retazos de discursos políticos y descripciones de movimientos de tropas, epílogos de las diferentes «estampas» de los frentes que se hicieran populares durante el conflicto, no escondían sin embargo una evidente misión exaltadora de las virtudes militares de Franco y de su ejército, además de una visión denigratoria del Ejército Popular republicano, mostrado en términos exclusivamente de cobardía, desorganización, traición y desafección ${ }^{91}$. Sin embargo, el género parahistoriográfico de mayor éxito después de la Victoria no fue el bélico, sino el político-jurídico, el propagandístico y el rememorativo. Y, en particular, el relativo al denominado terror rojo, desde los relatos de excautivos a los martirologios eclesiales, pasando por las descripciones de las checas, los centros de detención y tortura esparcidos por la retaguardia republicana ${ }^{92}$.

En realidad, se trataba de narraciones directamente herederas de la literatura publicada con profusión durante la Guerra Civil. El mismo maniqueísmo barroco y sin matices, igual repertorio de martirios y aberraciones, la misma necesidad de legitimar con hechos probados los procesos de represión política llevados contemporáneamente a cabo contra los vencidos. El consejo de guerra celebrado el 12 de junio de 1939 contra Alfonso Laurencic, un «engendro de hombre», por la apertura de las checas de las calles Vallmajor y Zaragoza en Barcelona, pondría de manifiesto la importancia dada al conocimiento y divulgación de la criminalidad, vesania y perversidad humanas, «lo que era la Justicia Roja en la España esclavizada y depauperada por los Negrines, Azañas, Companys y Comoreras» ${ }^{93}$. En el juicio Laurencic, a quien se acusaba de haber diseñado las celdas de tortura y pertenecer al organigrama directivo de las cárceles secretas, alegaría haber sido coaccionado, tener doble personalidad y haber colaborado, en su supuesta labor de espionaje doble, a que los «martirios» fuesen menores: «Aquí está mi mérito», diría. «Si yo no hubiera

\footnotetext{
90 VINCENT, 4 (Salamanca, 2007): 70.

${ }^{91}$ MARTÍNEZ CACHERO, 2009: 121 y ss.

92 CIAS, s.r.

${ }^{93}$ CHACÓN, 1939: 8.
} 
construido esas celdas, éstas, seguramente, hubieran sido veinte mil veces peor».

Esos méritos serían fuertemente contrarrestados por los testimonios de internos que pasaron por las celdas ideadas por Laurencic y, sobre todo, por el alegato patriótico de la fiscalía. La imposición de la pena de muerte «en garrote vil» pedida por el fiscal fue ratificada por el tribunal. Se reclamaría, como señalaría el fallo, que se tratase además de una «ejecución de la pena impuesta» para la «debida ejemplaridad», siendo fusilado el 9 de julio del 39 en el Campo de la Bota. «De cristianos es perdonar», anotaría Chacón, "ipero, cuántos inocentes murieron por su culpa, extenuados en noches horribles y en días que eran noches también, atormentados, supliciados, torturados por la aparatosa, infernal máquina ideada con satanismo increíble por la artera maña de Laurencic!» ${ }^{94}$. El autor acabaría agradeciendo al tribunal su sentencia. Le movían motivos patrióticos. Y además, la seguridad de que, con el antecedente de Laurencic, se perseguiría, juzgaría y castigaría a los responsables intelectuales y a los ejecutores de los vejámenes y villanías cometidas en los centros de detención y tortura.

Para los fascistas, la nación regenerada solamente podría demostrar su vitalidad mediante la agresión, la capacidad de reacción y su disposición a la guerra, la «santa guerra» de la que hablara Ernesto Giménez Caballero, y a la violencia, el sufrimiento, el martirio, la sangre. La guerra, justa y sana, latente en la naturaleza humana, fenómeno sublime, reflejo de las exigencias de los pueblos jóvenes, era el privilegio de unas pocas generaciones. La inmolación de los «mejores» entre ellos llenó los martirologios de los regímenes y movimientos fascistas, con la salvedad evidente que fue en España donde se acumularon los volúmenes más gruesos ${ }^{95}$.

El género parahistoriográfico de mayor éxito en la inmediata posguerra fue, de hecho, el de los martirologios de los caídos por Dios y por España, incluido el Mártir por excelencia, José Antonio Primo de Rivera, elevado a los altares de la patria con el impulso de sus acólitos y con el del Estado, que llegó incluso a hacer de su muerte una pieza completa de la Causa General. Beltrán Güell sería su autor más reconocido, en tanto que biógrafo de Caudillo, Profetas (José Antonio, Calvo Sotelo, Onésimo Redondo, Víctor Pradera) y Soldados (Sanjurjo, Mola, Goded, Orgaz, Fanjul, Queipo, Saliquet, Dávila, Varela y Ponte) ${ }^{96}$. Pero los medios falangistas, de hecho, se lanzaron rápidamente a la elaboración de biografías de los José Antonio, Ledesma Ramos u

94 CHACÓN, 1939: 35, 75, 100.

95 ZUNINO, 1995: 355. FALASCA-ZAMPONI, 1997. Para España, en parte, BOX, 2011.

96 BELTRÁN, 1939b, con retratos de Alejo Vidal Quadras 
Onésimo Redondo ${ }^{97}$, aunque sería, como resulta evidente, la del Ausente la figura más fuertemente idealizada. Para Francisco Bravo, de su figura emanaba un «fluido especial, misterioso» ${ }^{98}$, una irresistible atracción. La muerte de José Antonio y la narración construida a su alrededor afianzan, sin duda, el carácter heterogéneo de un relato de Cruzada con mártires religiosos, pero también mártires laicos como el mismo Ausente. Si los caídos bajo el manto del terror rojo estaban destinados a marcar los caminos de la santidad, para la retórica falangista José Antonio era una transfiguración del mismo Jesucristo. A Giménez Caballero todo lo relacionado con el asesinato en Alicante le recordaba «el drama cristiano de la Pasión. El mismo paisaje bíblico, judaico, de Palestina. Cerros ásperos, atroces y pelados. Rostros de judíos y de fariseos abrumados por su atroz crimen. Y en medio del sol y del cielo azul, y de la aparente serenidad del ambiente, veo cernirse sobre ti, ciudad de Alicante, el horrendo pecado de aquella crucifixión» ${ }^{99}$. La «época decadente» había finalizado con la llegada del «Mesías de hoy», enviado por Dios para que difundiese «la doctrina Nacional Sindicalista» ${ }^{100}$. José Antonio era el primer guerrero teólogo, decía Vela Utrilla.

El Movimiento albergaba sin embargo tras las cortinas de la unidad más contradicciones de las deseadas por sus protagonistas, y el caso de la Historia de la Cruzada parece uno de los más claros. Ismael Saz lo utiliza como ejemplo de diferencias en el tratamiento de un tema sensible como la definición originaria del tiempo y el proceso fundacional, la guerra. Laín rechazó formar parte del grupo de los «cruzadógrafos», declinándolo sobre Pérez Bustamante: «¿Historia de 'la Cruzada' y dirigida por Arrarás? Aquello 'no me iba'; 'no nos iba', podría decir, pensando en el común espíritu del grupo burgalés», escribiría a toro muy pasado Laín ${ }^{101}$. Ridruejo, por su parte, le dedicaría una crítica durísima que incluiría el concepto mismo de Cruzada, un «peligroso error del título», en la reseña anónima a uno de los volúmenes de Ararrás publicada en el número 6 de Escorial. Integrado ya Ridruejo en la División Azul, sería Laín quien tomaría las riendas del debate desde Escorial, afirmando que además de la carencia de adecuación de la Cruzada como relato, ni la Santa Sede, ni desde luego «José Antonio y Ramiro Ledesma, nuestros dos Fundadores» estarían de acuerdo con ella. La breve escalada de editoriales concluiría con la llamada al orden de Arriba: «Reivindicamos para el falangismo el concepto de Cruzada», y la del 36 lo había sido, «cierta y sacrosan-

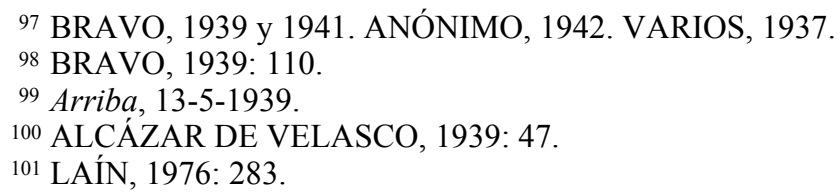


ta» ${ }^{102}$, contribuyendo con ello a la derrota de una concepción de la guerra que no fuese la de Cruzada, la del Franco salvador, la del sentido religioso que Gomá y los obispos habían contribuido a estandarizar y que se expandió por la España nacional de manera irrefrenable, hasta alcanzar, de hecho, la literatura propagandística, parahistoriográfica y memorial de manera neta. Saz no duda en calificar la querella sobre la pertinencia del término como feroz ${ }^{103}$ : suponía el epítome del enfrentamiento interno, dentro del mismo espacio fascistizado, entre el nacionalismo reaccionario radical y el fascismo modernizador, totalizador y revolucionario.

\section{CODA: DOS CRUZADAS}

Hubo pues polisemia, minimizada por mor de las necesidades de construcción identitaria en tiempo de guerra, y cuyos significados llegarían a enfrentarse en contextos diferentes. Con la decidida intención de alinear al Nuevo Estado con una tradición histórica gloriosa que rescatase del pasado la huella imperecedera y triunfal de la nación española, católica e imperial, la Cruzada tendría un alto «valor histórico y civilizador», por haber servido para acabar con los tres grandes enemigos de España («la masonería, el liberalismo antiespañol y el marxismo bolchevista»), por haber dotado al mundo de un «tema de meditación» y de escarmiento el martirio por la «barbarie roja»y por haber demostrado al mundo - un canto que, en boca de un falangista de primera hora y disidente durante la guerra, es demostración del consenso al que se habría llegado en torno a la definición de Cruzada - que el Ejército era la pieza clave para el ascenso de los regímenes fascistas europeos ${ }^{104}$.

Las páginas de El Español, periódico dirigido por el Delegado Nacional de Prensa Juan Aparicio (el colaborador más cercano a Ramiro Ledesma, fundador de La Gaceta Literaria, de La Conquista del Estado y, entre otros méritos, autor del lema Una, Grande y Libre) estuvieron entre las que más se fajarían en el combate por el relato y la interpretación de la guerra. Y, si en su primera página abría con la síntesis joseantoniana del guerrero y teólogo, no le andaba a la zaga Agustín del Río, para quien - como era, por otro lado, habitual en el discurso excombatentista - no cabía dejar caer en el olvido las verdades fundacionales, enraizadas en «la entraña misma de la victoria», ganadas «por la sangre de una juventud», que sustanciaban el «Nuevo Estado totalitario»: la heroicidad de Falange, la victoria, la voluntad de Franco ${ }^{105}$. La

\footnotetext{
102 Arriba, 20-2-1942.

${ }^{103}$ SAZ, 71 (Madrid, 2008): 165. Sobre la misma, SAZ, 2003: 320 y ss.

104 RODRÍGUEZ TARDUCHY 1941: 167.

${ }^{105}$ El Estado Nacional-sindicalista, en El Español, n. 1, 31-10-1942, p. 2.
} 
«singularidad española dentro de los movimientos totalitarios europeos es indudable»: un «catolicismo heroico y alegre, actual e histórico. Su sentido humano es religioso y no académico», cuyo contorno externo quedaría marcado por los enemigos. «La Cruzada española y la División Azul son buenas piedras de toque para entender».

Y esta última referencia no sería banal. Antes bien, entroncaba con la experiencia que, de otra Cruzada, venía viviendo parte del fascismo español, excombatiente o no de la Guerra Civil, desde 1941. En La Joven Europa, una sorprendente revista editada en Berlín en la que Ernesto Giménez Caballero cantaría las glorias de Franco, «nuevo Cisneros quizá de España», de su «Imperio» y del «mismo destino entre España y Alemania (...) gracias a la gloria militar del Führer» ${ }^{106}$, el periodista Alfredo Marquerie ${ }^{107}$ loaría los «planes de Adolf Hitler y del nacional-socialismo (...) [para] proyectar hacia fuera sus aspiraciones de justicia y de equidad». Una labor necesitada de una «nueva organización de Europa», tan «poderosa y tan bella que sólo puede ser realizada por un hombre genial y por un pueblo heroico, educado y disciplinado en las más altas virtudes del servicio y del sacrificio», y para la que encontraría una evidente línea de continuidad, incluso narrativa, entre la España de la Cruzada y la «Cruzada contra el comunismo - fase de la guerra en la cual nos hallamos»,

un primer eslabón para la forja de la unidad de Europa, fraguado en el ideal común y en la hermandad de las armas. Ni Francia ni Inglaterra habían comprendido que el bolchevismo era el enemigo público número uno de la humanidad (...) La batalla a la URSS sólo la podían iniciar Alemania y los países del Eje, no contaminados del virus comunista, vacunados contra él por sus propios regímenes.

$Y$ en esa batalla España no podía faltar a la cita pidiendo y obteniendo un puesto de honor y de peligro a la Alemania de Hitler, a la Alemania nacionalsocialista que la había ayudado con los heroicos legionarios de la Cóndor en la guerra entablada en 1936 dentro de la Península ibérica, para expulsar a los bolcheviques y exterminar a sus aliados traidores a la Patria.

Nuestra División Azul de voluntarios falangistas (...) nació espontáneamente el día mismo en el que Alemania entraba en guerra con la URSS (...) Y desde aquel instante, con la anuencia y apoyo de nuestro Caudillo y con el asenso del Führer, la División Azul era un hecho. Sólo hubo un problema: limitar el número de inscripciones, porque todos nuestros falangistas y excombatientes querían participar en la ocasión que, con frase de Cervantes, pudiera llamarse la más alta que ha visto la Historia. $51-57$.

${ }^{106}$ La Espiritualidad Española y Alemania, en La Joven Europa, cuaderno 3, 1942, pp.

${ }^{107}$ La organización de Europa y la Cruzada contra el Comunismo, en La Joven Europa, cuaderno 1/2, 1942, pp. 5-7. 
Ya no era Lepanto sino otra Cruzada la ocasión más grande de la historia, para la que la juventud española y europea se había erigido en «verdaderos combatientes», luchadores de primera línea: «entre Leningrado y Odessa (...) a través de dilatadas llanuras e impenetrables bosques contra el bolchevique adversario de toda cultura; otros luchan en las Universidades y altos centros de investigación contra las teorías funestas de un egoísmo desenfrenado». En esa hora terrible, «recordemos», decía La Joven Europa, «que formamos una comunidad europea, grande y joven, celosa guardadora de nuestros valores del pasado, pero también con aliento revolucionario». La guerra era, para los fascistas, el elemento cohesionador, la experiencia fundacional, la sustancia del proyecto de conquista armada del poder.

La Cruzada había sintetizado la historia de la nación, del mismo modo en que, por otro lado, los cruzados, los caídos y el terror rojo de 1936-39 se mezclarían con los de la otra cruzada a la que estaba llamada el régimen franquista. Al igual que Franco situó la naturaleza de la Cruzada en el carácter internacional del conflicto y en su naturaleza antibolchevique, en 1941 el relato de la Cruzada de 1936-39 albergaba otro objetivo directo e inmediato: el de legitimar esa otra que estaba desarrollándose en tierras del enemigo ontológico, de la Rusia comunista. En una conferencia en 1945, Luis Legaz Lacambra había esbozado las trazas de una doctrina de neutralidad «trascendente», pues así era su verdad: la que no por española, sino por superior, habría de «salvar al mundo». La de la guerra justa y la «recristianización del hombre y de la sociedad» ${ }^{108}$. Como se diría en un telegrama girado a Sudamérica a efectos de explicar el significado de la División Azul, «Recogiendo sentimiento popular, Falange organizó División voluntarios (...) a luchar con carácter Cruzada contra enemigo civilización cristiana occidental» ${ }^{109}$.

Cuando coincidiendo con el vigésimo aniversario de la fundación de Falange se celebrase en 1953 el Primer Congreso Nacional de FET-JONS, se pondría de relieve la determinación de Falange por «no ceder el menor terreno» a nadie que pudiera amenazar los equilibrios de fuerzas. Nada, ninguna voz discordante podría amenazar la «Unidad de la Victoria», nada podría traicionar la «gloriosa unanimidad de sacrificio en la Cruzada». De otra Cruzada, esa vez en Rusia, regresarían un año después los últimos divisionarios, los «mejores falangistas», los «vencidos dentro de los vencedores» muertos o cautivos. Su llegada, cargada de simbolismo y parafernalia, sellaría posiblemente el fin de una ritualidad fascista. Pero para entonces, la Cruzada había sido objeto de debates y disputas, convirtiéndose en el relato generado por la comunidad mnemónica por excelencia, que no es la fascista ni la católica ni otra, sino propiamente el Estado.

${ }^{108}$ LEGAZ LACAMBRA, 1947: 83.

${ }^{109}$ Cit. en DELGADO, 1992: 188. 
La narración de la Cruzada fue, por fin, estrictamente observada y fiscalizada por el Régimen. Y desde luego, Franco en este sentido fue coherente. Nadie puede decir que no cumpliese con lo cuanto dicho en 1937, en su discurso por la Unificación, en el que ya avisaría que «en los lugares de la lucha, donde brilló el fuego de las armas y corrió la sangre de los héroes, elevaremos estelas y monumentos, en que grabaremos los nombres de los que con su muerte, un día tras otro, van forjando el temple de la Nueva España». El 23 de septiembre de 1941, el decreto sobre «Obras referentes a la Guerra de Liberación o su preparación» pretendía que no se desvirtuase el sentido del Movimiento Nacional, y para ello disponía que «Las entidades y personas civiles y militares», los autores, editores o traductores «de obras en las que se trate de la campaña de nuestra Cruzada (...) las someterán a la previa autorización del Ministerio del Ejército», todo ello «sin prejuicio de cumplimiento de las disposiciones que regulan toda clase de publicaciones», es decir, la censura. En este caso, doble: política y militar ${ }^{110}$. En la construcción simbólica del franquismo sería, así, fundamental el control y la gestión, diríamos ahora, de dos relatos históricos en clave legitimadora: el del pasado, y el de las víctimas. El lejano, pues, pero también el inmediato, entendido en clave de continuidad. Caudillo, 18 de julio, Victoria, Cruzada: salir de los perímetros marcados por esos conceptos sería la única manera de oponer un contrarrelato, y no matices, tal vez nada más que variaciones sobre el mismo tema.

\section{BiBLIOGRAFÍA}

Albert, Mechthild, "'La guardia de los hijos de la noche'. Los intelectuales fascistas en Vértice (1937-1939), en Morente, Francisco y Gallego, Ferran (eds.), Rebeldes y reaccionarios. Intelectuales, fascismo y derecha radical en Europa, Barcelona, El Viejo Topo, 2011; 157-179.

Alcázar de Velasco, Ángel, José Antonio. Hacia el sepulcro de la fe, Burgos, Editorial Cóndor, 1939.

Alted, Alicia, Política del nuevo Estado sobre el patrimonio cultural y la educación durante la guerra civil española, Madrid, Ministerio de Cultura, 1984.

Álvarez Bolado, Alfonso, Para ganar la guerra, para ganar la paz. Iglesia y Guerra Civil, 1936-1939, Madrid, UPCO, 1995.

Álvarez, José Antonio et. al., La Guerra que aprendieron los españoles. República y guerra civil en los textos de bachillerato (1938-1983), Madrid, Los Libros de la Catarata, 2000.

Andrés-Gallego, José, ¿Fascismo o estado católico? Ideología, religion y censura en la España de Franco, 1937-1941, Madrid, Encuentro, 1997.

${ }^{110}$ Cit. en MORADIELLOS, 50 (Madrid, 2003): 17. 
Anónimo, El por qué del movimiento nacional, Salamanca, Servicio Prensa EspañaSur América, 1937.

Anónimo, Ramiro Ledesma, fundador de las JONS, Madrid, Vicesecretaría de Educación Popular, 1942.

Arrarás, Joaquín (dir.), Historia de la Cruzada Española, 7 vols., Madrid, Ediciones Españolas, 1938-1944.

Ayape de San Agustín, Eugenio, Sangre de España. Espíritu y virtud de la Cruzada española, Manizales, Tip. San Agustín, 1939.

Azpiazu, Joaquín, ¡Por Dios y por la Patria! El patriotismo como virtud cristiana, Burgos, Cultura y Acción, 1938.

Beltrán Güell, Felipe, Rutas de la victoria, Barcelona, R. Farré, 1939a.

Beltrán Güell, Felipe, Caudillo, profetas y soldados, Madrid-Barcelona, Editorial Juventud, 1939b.

Beltrán Güell, Felipe, Preparación y desarrollo del Alzamiento Nacional. Ensayo histórico, Valladolid, Librería Santarén, 1939c.

Beneyto, Juan, El nuevo Estado español. El régimen nacional sindicalista ante la tradición y los demás sistemas totalitarios, Madrid y Cádiz, Biblioteca Nueva, 1939.

Berdión, Auxilio, Madrid en tinieblas: siluetas de la revolución, Salamanca, Imprenta Comercial Salmantina, 1937.

Borrás, Tomás, Checas de Madrid, Cádiz [1939], reed. en Madrid, Editora Nacional, 1944.

Botti, Alfonso, Cielo y dinero. El Nacionalcatolicismo en España, 1881-1975, Madrid, Alianza, 1992.

Bravo, Francisco, José Antonio. El Hombre, el Jefe, el Camarada, Madrid, Ediciones Españolas, 1939.

Bravo, Francisco, José Antonio ante la justicia roja, Madrid, Vicesecretaría de Educación Popular, 1941.

Carreras, Lluis, Grandeza cristiana de España. Notas sobre la persecución religiosa, Toulouse, Douladoure, 1938.

Castro Albarrán, Aniceto, Guerra Santa: el sentido católico del Movimiento Nacional español, Burgos, Editorial Española, 1938a.

Castro Albarrán, Aniceto, Este es el cortejo. Héroes y mártires de la cruzada española, Salamanca, Gráficas Cervantes, 1938 b.

Castro Albarrán, Aniceto, La gran victima, la Iglesia española mártir de la revolución roja, Salamanca, Gráficas Cervantes, 1940.

Castro Albarrán, Aniceto, El derecho al Alzamiento, Salamanca, 1941.

Cazorla, Antonio, «Patria Mártir: los españoles, la nación y la guerra civil en el discurso ideológico del primer franquismo», en Moreno, Javier (ed.), Construir España, Madrid, CEPC, 2007; 289-302.

Chacón, Rafael, Por qué hice las Chekas de Barcelona. Laurencic ante el Consejo de Guerra, Barcelona, Editorial Solidaridad Nacional, 1939. 
CIAS, Cómo funcionaban las Chekas de Barcelona, Barcelona, Publicaciones del CIAS-Acción contra la III Internacional, s.r.

Cobo, Francisco, «El franquismo y los imaginarios míticos del fascismo europeo de entreguerras», Ayer, 71 (Madrid, 2008), 117-151.

Cobo, Francisco y Ortega, Teresa María, Franquismo y posguerra en Andalucía oriental. Represión, castigo a los vencidos y apoyos sociales al régimen franquista, 1936-1950, Universidad de Granada, 2005.

Codornié, Rafael, Madrid bajo el marxismo (estampas), Madrid, Librería General de Victoriano Suárez, 1939.

Cossio, Francisco de, Guerra de salvación: del frente de Madrid al de Vizcaya, Valladolid, Librería Santarén, 1937.

Cruz, Rafael, «`¿Luzbel vuelve al mundo! Las imágenes de la Rusia soviética y la acción colectiva en España», en Cruz, Rafael y Pérez Ledesma, Manuel (eds.), Cultura y movilización en la España contemporánea, Alianza, Madrid, 1997; 273-303.

De Armas, Francisco, Estampas de la Guerra, s.r., Editorial Canaria, 1937.

De Foxá, Agustín, Madrid, de corte a checa, Salamanca, Jerarquía, 1938.

Del Arco, Miguel Ángel, Hambre de siglos. Mundo rural y apoyos sociales del franquismo en Andalucía Oriental (1936-1951), Comares, Granada, 2007.

Delgado, Lorenzo, Imperio de papel. Acción cultural y politica exterior durante el primer franquismo, Madrid, CSIC, 1992.

Di Febo, Giuliana, Ritos de guerra y de victoria en la España franquista, Bilbao, Desclée de Brouer, 2002.

El preso 831, Del Madrid rojo. Últimos días de la Cárcel Modelo, Cádiz, Establecimientos Cerón, 1937.

Eguía, Constancio, Los causantes de la tragedia española, s.r., Ed. Difusión, 1938.

Esterlich, Joan, La persecución religiosa en España, Buenos Aires, Difusión, 1937.

Falasca-Zamponi, Simonetta, Fascist spectacle. The aesthetics of power in Mussolini's Italy, Berkeley University of California Press, 1997.

Fernández Almagro, Melchor, Historia de la República Española, Madrid, Biblioteca Nueva, 1940.

Fernández Arias, Adelardo, Madrid bajo el terror, 1936-1937. (Impresiones de un evadido, que estuvo a punto de ser fusilado), Zaragoza, Librería General, 1937.

Fernández Arias, Adelardo, La agonía de Madrid, 1936-1937. (Diario de un superviviente), Zaragoza, Librería General, 1938.

Fernández Plorez, Wenceslao, Una isla en el mar rojo, Madrid, Ediciones Españolas, 1939.

Fonteriz, Luis de, Seis meses bajo el terror rojo en Madrid, Ávila, Senén Martín Díaz, 1937.

Foronda, Ana María, Nueve meses con los rojos en Madrid, Ávila, Imprenta Católica Sigirano Díaz, 1937. 
Gallego, Ferran, «Ángeles con espadas. Algunas observaciones sobre la estrategia falangista entre la revolución de octubre y el triunfo del Frente Popular», en Gallego, Ferrán y Morente, Francisco (eds.), Fascismo en España. Ensayos sobre los orígenes sociales y culturales del franquismo, El Viejo Topo, Barcelona, 2005a; 179-209.

Gallego, Ferran, «La realidad y el deseo. Ramiro Ledesma en la genealogía del franquismo», en Gallego, Ferran y Morente, Francisco (eds.), Fascismo en España. Ensayos sobre los orígenes sociales y culturales del franquismo, El Viejo Topo, Barcelona, 2005b; 253-447.

Gallego, Ferran, «Construyendo el pasado. La identidad del 18 de julio y la reflexión sobre la historia moderna en los años Cuarenta», en Gallego, Ferran y Morente, Francisco (eds.), Rebeldes y reaccionarios. Intelectuales, fascismo y derecha radical en Europa, El Viejo Topo, Barcelona, 2011; 281-337.

Gallego, Ferran, El evangelio fascista. La formación de la cultura política del franquismo (1930-1950), Barcelona, Crítica, 2014.

García, Hugo, «Relatos para una guerra: terror rojo, testimonio y literatura en la España nacional, 1936-1939», Ayer, 79 (Madrid, 2009), 143-176.

García Alonso, Francisco, Mis dos meses de prisión en Málaga, Sevilla, Tipografía de M. Carmona, 1936.

Garán, Justo, Sofismas y razones. Del ateismo legal a la restauración, Valladolid, Casa Martín, 1939.

Gomá, Isidro, Por Dios y por España. 1936-1939, Barcelona, Casulleras, 1940.

González Calleja, Eduardo, «La violencia y sus discursos: Los límites de la 'fascistización' de la derecha española durante el régimen de la Segunda República», Ayer, 71 (Madrid, 2008),85-116.

González Calleja, Eduardo, Contrarrevolucionarios. Radicalización violenta de las derechas durante la Segunda República, 1931-1936, Madrid, Alianza, 2011.

Hernández Burgos, Claudio, Granada azul. La construcción de la «Cultura de la Victoria» en el primer franquismo, Granada, Comares, 2011.

Juliá, Santos, «De guerra contra el invasor a guerra fratricida», en Id. (ed.), Víctimas de la guerra civil, Madrid, Temas de Hoy, 1999, 11-54.

Juliá, Santos, Historias de las dos Españas, Madrid, Taurus, 2004.

Laín, Pedro, Descargo de conciencia (1930-1960), Barcelona, Barral, 1976.

Ledesma, José Luis y Rodrigo, Javier, «Caídos por España, mártires de la libertad. Víctimas y conmemoración de la Guerra Civil en la España posbélica», Ayer, 63 (Madrid, 2006), 233-255.

Legaz Lacambra, Luis, Horizontes del pensamiento jurídico: estudios de filosofía del derecho, Barcelona, Bosch, 1947.

Marrero, Vicente, La guerra española y el trust de cerebros, Madrid, Ediciones Punta Europa, 1961.

Martínez Cachero, José María, Liras entre lanzas. Historia de la literatura «nacional» en la Guerra Civil, Madrid, Castalia, 2009. 
Martínez, Juan de la Cruz, ¿Cruzada o rebelión? Estudio histórico-jurídico de la actual guerra de España, Zaragoza, Librería General, 1938.

Mazorra Setién, José Joaquín, 57 Semanas de angustia. Trozos de las memorias de un Caballero de España sobre episodios de la revolución roja de 1936, en la Montaña, Santander, Imp. Casa Maestro, 1937.

Meinvielle, Julio, Qué saldrá de la España que sangra, Buenos Aires, Secretariado de Publicaciones de la Asociación de los Jóvenes de la Acción Católica, 1937.

Miquelarena, Jacinto, Cómo fui ejecutado en Madrid, Ávila, Imprenta Católica Sigiriano Díaz, 1937.

Montero, Eloy, Los Estados modernos y la nueva España, Vitoria, Montepío Diocesano, 1939.

Moradiellos, Enrique, «Ni gesta heroica, ni locura trágica: nuevas perspectivas históricas sobre la guerra civil», Ayer, 50 (Madrid, 2003); pp. 11-39.

Morente, Francisco, «Más allá del páramo. La historia de los intelectuales durante el franquismo», en Frías, Carmen, Ledesma, José Luis y Rodrigo, Javier (eds.) Reevaluaciones. Historias locales y miradas globales, Zaragoza, Institución Fernando el Católico, 2011, 41-76.

Morente, Francisco, «Rafael Sánchez Mazas y la esencia católica del fascismo español». en Ruiz Carnicer, Miguel Ángel (ed.), Falange. Las culturas políticas del fascismo en la España de Franco, Zaragoza, Institución Fernando el Católico, 2013a, 109-141.

Morente, Francisco, «Los falangistas de Escorial y el combate por la hegemonía cultural y política en la España de la posguerra», Ayer, 92 (Madrid, 2013b); 173-196.

Morodo, Raúl, Los orígenes ideológicos del franquismo: Acción Española, Madrid, Alianza, 1985.

Núñez Seixas, Xosé Manoel, ¡Fuera el invasor! Nacionalismos y movilización bélica en la Guerra Civil española, 1936-1939, Madrid, Marcial Pons, 2006.

Olmedo, Félix, El sentido de la guerra española, Bilbao, El Mensajero del Corazón de Jesús, 1938.

Ortega, Teresa María, «¡Cosa de coser... y cantar! La derecha antiliberal y el adoctrinamiento político de la mujer de clase media en la Segunda República», en Id. y Aguado, Ana (eds.), Feminismos y antifeminismos. Culturas politicas e identidades de género en la España del siglo XX, Valencia y Granada, Universitat de València y Universidad de Granada, 2011, 173-206.

Panés, Antonio., Estampas de la revolución, Madrid, Imprenta Madrid-Aragón, 1941.

Pemartín, José, Qué es «lo nuevo»: consideraciones sobre el momento español presente, Sevilla, Cultura Española,1937.

Pemartín, José, Los orígenes del Movimiento, Burgos, Hijos de Santiago Rodríguez,1938.

Pérez de Olaguer, Antonio, El terror rojo en Cataluña, Burgos, Ediciones Antisectarias, 1937. 
Pérez de Olaguer, Antonio, El terror rojo en Andalucía, Burgos, Ediciones Antisectarias, 1938.

Pérez de Olaguer, Antonio, El terror rojo en la Montaña, Barcelona, Ediciones Juventud,1939.

Puig Mora, E., La tragedia roja en Barcelona. Memorias de un evadido, Zaragoza, Librería General, 1937.

Richards, Michael, «El Régimen de Franco y la política de memoria de la guerra civil española», en Guerra civil. Mito y memoria, Madrid, Marcial Pons, 2006, 167-200.

Robledo, Ricardo, «La iglesia salmantina: rebeldía, cruzada y propaganda. El Centro de Información Católica Internacional», en Robledo, Ricardo (ed.), Esta salvaje pesadilla. Salamanca en la guerra civil española, Barcelona, Crítica, 2007, 71-98.

Rodríguez del Castillo, Jesús, Vida y muerte en las cárceles rojas, Tudela, Imprenta Católica Larrad, 1938.

Rodriguez Puértolas, Julio, Historia de la literatura fascista española, 2 vols., Madrid, Akal, 2006 (or. 1986-1987).

Rodríguez, Javier, León bajo la dictadura franquista (1936-1951), Universidad de León, 2003.

Ros, Félix, Preventorio D. Ocho meses en la cheka, Barcelona, Yunque, 1939.

Sanabria, Fernando, Madrid bajo las hordas (Via Dolorosa de la Capital de España), Ávila, Shade, 1938.

Saz, Ismael, España contra España. Los nacionalismos franquistas, Madrid, Marcial Pons, 2003.

Saz, Ismael, «Las culturas de los nacionalismos franquistas», Ayer, 71 (Madrid, 2008): 153-174.

Sevillano, Francisco, Rojos. La representación del enemigo en la Guerra Civil, Madrid, Alianza, 2007.

Suñén, Enrique, Los intelectuales y la tragedia española, San Sebastián, Editorial Española, 1938.

Tello, José Ángel, Ideología y política. La Iglesia Católica española (1936-1959), Zaragoza, Pórtico, 1984.

Varios, Onésimo Redondo, Caudillo de Castilla, Valladolid, Ediciones Libertad, 1937.

Vincent, Mary, «La Guerra Civil española como guerra de religión», Alcores, 4 (Salamanca, 2007); pp. 57-73.

Ximénez de Sandoval, Felipe, José Antonio, biografía apasionada, Barcelona, Editorial Juventud, 1941.

Zunino, Pier Giorgio, L'ideologia del fascismo. Miti, credeze e valori nella stabilizzazione del regime, Bolonia, Il Mulino, 1995.

Recibido: $19 / 04 / 2012$

Aceptado: 14/11/2012 